\title{
LA SUFIXACIÓ APRECIATIVA DEL CATALÀ: CREACIONS LĖXIQUES I IMPLICACIONS MORFOLÒGIQUES
}

\author{
APPRECIATIVE SUFFIXATION IN CATALAN: LEXICAL \\ INNOVATIONS AND MORPHOLOGICAL CONSEQUENCES \\ Maria-Rosa Lloret \\ Universitat de Barcelona \\ mrosa.lloret@ub.edu
}

Resum: La situació de la derivació apreciativa dins la morfologia és excepcional, perquè la informació limitada que contenen, en general, les gramàtiques i els diccionaris sobre els apreciatius així com l'ús habitual d'aquestes formes en contextos familiars i informals fan que la creativitat dels parlants no es vegi limitada per normatives i que, per tant, aflorin solucions imaginatives, que, tot i la variació existent, segueixen uns condicionaments gramaticals clars. L'objectiu d'aquest treball és aportar noves dades en aquest camp a partir de formes recollides en corpus tradicionals i per internet, amb una doble finalitat: d'una banda, aprofundir en les particularitats morfològiques de la sufixació apreciativa del català, amb especial interès per les de les categories que la bibliografia sovint ignora (és a dir, els apreciatius que no deriven de noms, adjectius o verbs); i, de l'altra, demostrar que les restriccions distribucionals que presenten els apreciatius amb relació a les terminacions que admeten tant les formes tradicionals com les noves creacions lèxiques permeten redefinir quines marques flexives nominals reals té el català.

Paraules clau: derivació apreciativa, neologismes, flexió nominal, marques flexives, gènere, català.

Abstract: The position of the appreciative derivation within morphology is exceptional, because, although the limited information that grammars and dictionaries reveal as for its formation and use, speakers freely use appreciative forms in familiar and informal contexts and often create new words without the restraints traditionally imposed by grammatical norms. As we will see, although the shape of these forms presents some variation, it complies with some well-defined constraints. This paper presents new data in this field collected through traditional corpora and internet, with a two-fold aim. The first purpose is to thoroughly examine the morphological characteristics of the appreciative suffixation in Catalan, with special reference to the categories usually ignored in the literature (i.e., appreciative forms derived from categories other than nouns, adjectives and verbs). The second purpose has to do with the distributional restrictions that traditional words and new creations show with respect to the endings they allow, in order to identify the true nominal inflectional marks of Catalan.

Key words: appreciative derivation, neologisms, nominal inflection, inflectional marks, gender, Catalan.

Caplletra 58 (Primavera, 2015), pp. 55-89 


\section{MARIA-ROSA LLORET}

\section{LA SUFIXACIÓ APRECIATIVA DEL CATALÀ: CREACIONS LËXIQUES I IMPLICACIONS MORFOLÒGIQUES}

\section{INTRODUCCIÓ}

En la formació de paraules, la morfologia apreciativa — també anomenada valorativa, afectiva, expressiva, aspectiva $\mathrm{o}$ intensiva pels matisos semàntics que introdueix-ocupa un lloc especial perquè no es tracta d'un cas típic de derivació en què es crea un nou mot, sinó que només s'altera semànticament la base lèxica que modifica, afegint-hi un matís de grandària, diminutiu (cotxet) o augmentatiu (cotxàs), o de valoració subjectiva, positiva si és afectiva (marona) o negativa si és despectiva (politiquet). De fet, l'ús de formes apreciatives no ve imposat per la gramàtica, sinó que queda a l'arbitri del parlant; mostra, a més, una forta interacció amb la pragmàtica, perquè el significat de base dels apreciatius sovint es veu alterat pel context, les actituds dels participants i l'acte de parla mateix (Apa, quin cotxet que thas comprat de 7 places:). En un bon nombre de casos el sufix apreciatiu ha perdut el matís aspectiu original per crear una nova unitat lèxica (cotxet «vehicle [...] destinat a portar-hi un infant o dos»). ${ }^{1}$

Des del punt de vista formal, una particularitat que presenta la morfologia apreciativa és que, de vegades, és difícil de copsar la vitalitat d'algunes construccions.

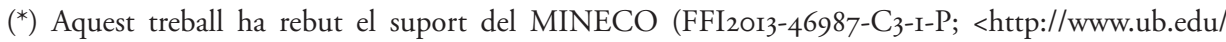
GEVAD>) i de la Generalitat de Catalunya (20I4SGR9I8). Agraeixo a Jesús Jiménez els valuosos comentaris aportats a la primera versió del treball. La redacció final de l'article també s'ha beneficiat dels suggeriments dels revisors anònims.

I. Les definicions dels mots lexicalitzats són del DIEC, excepte quan s'indica una altra font. 
Ningú no dubta, per exemple, que en català, amb el sufix diminutiu -et(a), cotxe fa cotxet; però: quin és el diminutiu de virus o de crisi? És viret o viruset? És criseta? O potser no existeixen per sufixació sinó que sempre s'usen amb la construcció "X petit(a)»: virus petit, crisi petita? I els pronoms personals i els possessius, poden tenir diminutius expressius com elleta i seveta? La dificultat de compilar aquest tipus de dades és palesa en el fet que, excepte quan es tracta d'una forma lexicalitzada, en general no es pot recórrer als diccionaris per comprovar-ne l'existència; en són una excepció el $D C V B$ i el $D D L C$, que recullen formes apreciatives habituals al costat de les entrades dels mots simples corresponents. El mètode tradicional d'enquesta o l'ús de corpus tradicionals tampoc no resolen del tot satisfactòriament el problema. La dificultat no és constatar la forma apreciativa dels mots que admeten, sense problemes, un ús aspectiu (cotxet, cotxàs, marona, politiquet...), sinó esperar que un parlant utilitzi espontàniament l'apreciatiu de mots poc usats amb valors aspectius (com ara virus, crisi, ella o seva) per determinar si existeixen o no i, si existeixen, quina forma prenen. Per sort, avui dia podem recórrer a cerques per internet per comprovar-sense necessitat que el lingüista hi intervingui- la creativitat lèxica dels parlants en contextos informals, en què l'ús de formes apreciatives és habitual. Malgrat les limitacions i els defectes metodològics que s'addueixen per a aquesta manera de recollir dades (no es controlen els informants i, per tant, no se'n coneix el perfil lingüístic, p. ex.), val la pena d'assajar-ne l'eficàcia i de veure, en aquest punt de difícil compilació de dades, quines són les tendències d'ús que mostren els parlants i quines dades afegeixen a les recopilades en corpus tradicionals.

L'objectiu d'aquest treball és analitzar les característiques formals dels apreciatius amb una doble finalitat: d'una banda, aprofundir en les particularitats morfològiques de la sufixació apreciativa del català i en les categories que l'admeten, qüestions que apareixen esparsament $\mathrm{i}$ incompletament tractades a la bibliografia $\left(\mathbb{\$}_{2}\right){ }^{2} \mathrm{i}$, de l'altra, demostrar, a partir de l'anàlisi de les formes recollides $\left(\$_{3}\right)$, que les restriccions distribucionals que presenten els apreciatius amb relació a les terminacions que admeten

2. Les monografies de lexicologia de Cabré \& Rigau (1986) i Cabré (1994) així com la Gramàtica del català contemporani toquen per sobre la formació apreciativa. Lloret (1996, 1998) aporta noves dades sobre la formació de diminutius, que Rull (2004: $\$ 8$ ) recull i amplia (veg. $\$$ 3.a). Recentment, Bernal (20I2) ha estudiat els problemes que comporten els apreciatius per a la traducció a partir d'exemples de tres contes de Rodoreda; tots els testimonis són, però, formes apreciatives habituals (bruixeta, peuets, petitona, etc.), que per tant no presenten les dificultats formals que es tracten en aquest treball. 
permeten redefinir quines marques flexives nominals reals té el català $\left(\$_{4}\right)$. S’hi afegeix un Annex per documentar exemples trobats per internet i al CTILC de les formes menys habituals objecte d'estudi. ${ }^{3}$

\section{DERIVACIÓ APRECIATIVA PER SUFIXACIÓ}

\section{A CARACTERITZACIÓ DE LA DERIVACIÓ APRECIATIVA}

La característica morfosintàctica més important que permet diferenciar els sufixos apreciatius dels sufixos lèxics és que no tenen valor recategoritzador; és a dir, no canvien ni determinen la categoria de la base, són transparents pel que fa a les categories lèxiques. ${ }^{4} \mathrm{~A}$ més, són els únics que es poden adjuntar a bases de diferents categories, com si també fossin transparents pel que fa als trets sintàctics. Així, si s'afegeixen a una base nominal, el resultat és un altre nom (cotxe, cotxet, cotxàs); si s'afegeixen a una base adjectival, el resultat és un altre adjectiu (gran, grandet, grandot); si s'afegeixen a una base adverbial, el resultat és un altre adverbi (aviat, aviadet, aviadot), i, si s'afegeixen a una base verbal, el resultat és un altre verb (ploure, ploviscar; allargar, allargassar).

Les quatre categories susdites són les que es reporten en la bibliografia com a susceptibles de crear apreciatius per sufixació en català; però altres categories en podrien admetre. Nieuwenhuis (1985: 223; op. cit. Dressler \& Merlini Barbaresi 1994: 93) arriba inductivament a la següent jerarquia universal per a les categories aptes per a la formació apreciativa, basada en els diminutius: noms $>$ adjectius $>$ verbs $>$ numerals $>$ interjeccions $>$ pronoms $>$ preposicions $>$ demostratius. ${ }^{5}$ En un estudi sobre

3. La recerca ha estat dissenyada a partir del treball de Lloret (2013), en què, tot replantejant el caràcter morfològic de les terminacions flexives dels elements nominals, es van tractar tangencialment les formes apreciatives incorporant cerques per internet. Els exemples no literaris extrets d'internet, localitzats mitjançant Google i comprovats durant el febrer de 20I3, s'han verificat amb un mínim de tres parlants (d'entre 20 i 30 anys, amb LI català i usuaris habituals de les noves xarxes socials virtuals), atenent diferències dialectals quan ha estat pertinent.

4. Els casos en què hi ha recategorització són formes lexicalitzades. Per exemple, del verb cagar deriva el nom cagarro (amb el sufix usat inicialment per crear augmentatius i despectius -arro), a partir del qual es creen els veritables apreciatius nominals (cagarret, cagarró, cagarrot, cagarràs).

5. La categoria pronoms inclou els personals i els possessius; no hi apareixen els adverbis, els quals en la jerarquia proposada per al rus per Bratus (1969: 3; op. cit. Dressler \& Merlini Barbaresi i994: 59I, n. I27) se situen al costat dels adjectius. 
els diminutius en italià, alemany i anglès, Dressler i Merlini Barbaresi (I994: I3I-I32) ratifiquen part de la jerarquia anterior i conclouen que noms i adjectius (per als quals no troben diferències significatives en la freqüència d'ús) són les bases preferides per formar apreciatius, perquè típicament admeten la dimensió de grandària; seguits dels verbs, perquè admeten intensificadors. Les altres categories no admeten gradació de grandària $i$, com que el significat de les formes apreciatives corresponents dependrà de la connotació i de la pragmàtica, el seu ús és universalment molt més limitat (sense que estableixin una ordenació per freqüència entre elles).

Les característiques morfològiques que identifiquen els sufixos apreciatius tenen a veure amb la flexió. D'una banda, mantenen les categories flexives de la base; per exemple, casa (femení) manté el femení a caseta, casal (masculí en virtut del sufix nominalitzador masculí -al) manté el masculí a casalet i tisores (plural inherent) manté el plural a tisoretes. De l'altra, els sufixos apreciatius solen substituir les marques irregulars de flexió per les regulars; així, el nom femení carn, que no presenta la terminació regular de femení - $a$, la mostra a carn-et- $a$, i el masculí gitan-o, amb terminació irregular $-o$, presenta la terminació regular zero ( $\varnothing \mathrm{o}$ absència de morf) de masculí a gitan-et.

Dues propietats formals més dels sufixos apreciatius són que apareixen immediatament abans de la flexió (cas-et-es, cas-al-et-s) i que poden combinar-se entre ells — si no són semànticament contraris - amb valor intensificador (a petit-on-et, p. ex., amb l'ús dels dos sufixos diminutius s'intensifica la disminució).

Per les particularitats de la morfologia apreciativa, que en molts casos s'acosta a les propietats de la flexió, alguns autors l'han situada a part de la derivació (pròpiament lèxica) i de la flexió, ocupant un nivell independent enmig de les dues en una morfologia ordenada per nivells (veg., entre altres, Scalise 1988: 233-237). Sembla, però, que, malgrat les característiques morfològiques, sintàctiques i semàntiques peculiars que presenta, no hi ha prou indicis — almenys en les llengües indoeuropees - per acceptar aquesta triple divisió (Dressler \& Merlini Barbaresi 1994: 92-93).

\section{B ELS SUFIXOS APRECIATIUS DEL CATALÀ}

Deixant de banda la mobilitat interpretativa determinada per la pragmàtica, entre els derivats amb sufixos apreciatius es distingeixen els que creen diminutius dels que creen augmentatius i despectius, els quals sovint s'anomenen conjuntament 
intensius en el cas dels derivats verbals (veg., p. ex., Fabra I956: \$ I50.viI). ${ }^{6}$ El significat bàsic dels sufixos diminutius és aportar, quant a grandària, el matís de petit o escàs i, quant a valoració subjectiva, un matís afectiu típicament positiu. En català, el sufix diminutiu més habitual és -et(a), que s'adjunta a bases nominals (cotxet, caseta), adjectivals (petitet(a)) i adverbials (llunyet). També és bastant habitual el sufix diminutiu -ó(na), que s'adjunta a bases nominals (animaló, casona) i, amb més freqüència, a bases adjectivals (petitó(na)). ${ }^{7}$ Amb menys abast geogràfic i vitalitat, -oi(a) s'adjunta a bases nominals (caminoi, ratoia) i, amb relativament més freqüència, a bases adjectivals (petitoi(a)). ${ }^{8}$ El sufix -i(na), que té bàsicament el valor lexicalitzat que comentem més avall, pot aparèixer en la segona posició de combinacions amb dos i tres sufixos, amb valor intensificador (nass-arr-in-et, mic-arr-in-ona) (sobre el sufix -arrola, veg. més avall). Tots els sufixos anteriors mantenen el gènere de les bases nominals i adjectivals.

Rull (2004: 304-308) recull que, en zones geogràfiques concretes, tenen vitalitat per a bases nominals i adjectivals altres sufixos diminutius: -iu(a), usat sobretot en tortosí i en valencià (trossiu, camiues, primiu(a)) i que també pot afegir-se a bases adverbials (propiu); -eu(a), usat en balear i residualment en valencià (boteu, catedraleua, negrusseu (a)); el.lola, usat sobretot en balear i sovint amb un cert to còmic (volcanel.lo, gotel.la, jovenel-lo/a), i, amb un ús molt més limitat, els sufixos d'origen italià -etxo/a, -itxola i -utxola, emprats sobretot en balear amb to despectiu (al-lotetxo, catedraletxa, cavallutxo, magritxola). L'alguerès usa -utxola (llitutxo, cambutxa, petitutxola) i, a vegades, del luogodorès, el sufix -edula (porquedu, micareda) (Veny I983: III). Com abans, tots mantenen el gènere de les bases nominals i adjectivals.

Per a bases nominals, existeixen altres sufixos diminutius no productius. Normalment apareixen en formes lexicalitzades que, com a màxim, mantenen el matís de grandària o de valoració subjectiva de forma residual (no serveixen per crear formes apreciatives noves, per tant). Alguns dels sufixos no alteren el gènere de la base, com

6. El fet que amb bases verbals el sufixos apreciatius sovint aportin un significat de tipus aspectual fa que en alguns tractats no s'estudiïn en l'apartat de la morfologia apreciativa sinó dins la derivació lèxica. A la $N G L E$, per exemple, es tracten dins la derivació lèxica; en canvi, a la nova gramàtica de la llengua catalana que prepara l'IEC (esborrany disponible a <www2.iec.cat/institucio/seccions/Filologica/gramatica/default.asp $>$ ) es tracten dins l'apartat de la sufixació apreciativa, tal com també fa la $G N V$, seguint la tradició de les gramàtiques catalanes.

7. Rull (2004: 300, n. 5) recull, per al mallorquí, l'ús afectiu del sufix -ó(na) en la forma flexionada de masculí plural (-ons) amb noms propis femenins: Marions (de Maria), Catalinons (de Catalina).

8. Al DF (I996: XXXVIII), p. ex., s'hi compten I6379 ocurrències del lema petit, de les quals I6 I54 són formes simples, 59 són derivades amb -et(a), 35 amb -ó(na), 7 amb -oi(a) i 2 amb el doble sufix -onet(a). 
ara -ol(a) (pujol, banderola) i -ell(a) (pomell, rosella); altres poden alterar-lo, com-ill(a) (manteniment a sabatilla, però canvi de gènere a cordill) i -i(na) (manteniment a tamborí, però canvi de gènere a paperina), i uns altres únicament han creat masculins, com -im (ventim, plugim), -inc (foradinc, esquellinc) i -ic (canic, bossic); -ic(a) també pot aparèixer amb una base adjectival (pobric(a)). El sufix -icola té vitalitat en valencià per a la formació d'afectius derivats de noms propis de persona: Pepico, Vicentica (Sanchis Guarner 1993: 210). Per a bases nominals i adjectivals, el sufix despectiu -us(sa) aporta un valor negatiu normalment relacionat amb disminució (carussa "cara pàl.lida o demacrada», pelussa «borrissol», malaltús(sa)), tot i que de vegades aporta matís de grandària (carnussa «abundància fastigosa de carn»); pot mantenir o no el gènere de les bases nominals (manteniment a carussa i carnussa, però canvi de gènere a carnús «excrescència carnosa» i a pelussa). En els noms, la capacitat dels sufixos anteriors d'alterar el gènere de la base — amb preferència envers la categoria no marcada (masculí) - els acosta formalment als sufixos derivatius lèxics, tal com també s'esdevé en alguns usos lexicalitzats de sufixos diminutius productius (com ara -ó(na), que crea noms masculins lexicalitzats com balançó "plat d'una balança»).

A partir de bases verbals de la primera conjugació, s'han creat verbs amb sufixos apreciatius que es tracten com a diminutius perquè denoten l'acció verbal en quantitat més petita o menys intensa, però que es troben lexicalitzats. Alguns dels sufixos que apareixen amb bases nominals i adjectivals també ocorren amb bases verbals: -ic(ar) (ploricar), -us(sar) o -ussej(ar) (menjussar; cantussar, cantussejar), -in(ar) (aixafinar) i -ol(ar) o -olej(ar) (penjolar-se, ventolejar). Altres, en canvi, només ocorren amb bases verbals: -isc(ar) o -isquej(ar) (ploviscar, plovisquejar), -iny(ar) (arrapinyar-se), -iss(ar) (adormissar-se), i amb matís despectiu, -uc(ar) o -uquej(ar) (menjucar, menjuquejar) i -usc(ar) o -usquej(ar) (treballuscar, tallusquejar). ${ }^{9}$

Per la seva banda, el significat bàsic dels sufixos augmentatius és aportar, quant a grandària, el matís de gran o abundós i, quant a valoració subjectiva, un matís afectiu típicament negatiu, que també aporten els sufixos despectius. Els sufixos augmentatius més habituals són -ot(a) i -às(sa), que s’adjunten a bases nominals (peuot, peuàss; festota, festassa) i adjectivals (grandot(a), grandàs $(s a)) \mathrm{i}$, per norma general, mantenen el gènere

9. Cal destacar, en alguns casos, la concurrència del sufix lèxic verbalitzador -ej(ar), obligatòriament amb algunes bases (tallusquejar, ${ }^{*}$ talluscar vs. treballuscar, ${ }^{*}$ treballusquejar) i alternativament amb altres (menjucar o menjuquejar vs. menjussar, *menjussejar), la qual cosa reforça el caràcter més aviat lexicalitzat d'aquests sufixos. D’acord amb Cabré (I994: 64), l'únic sufix verbal intensiu amb valor diminutiu és -isc(ar). 
de la base. Per a bases nominals, existeix el sufix força habitual -arrola (peuarro, festarra), que tampoc no canvia el gènere de la base i que sovint aporta un valor pejoratiu, tot i que - com hem vist més amunt- pren un valor afectiu positiu en combinacions de dos o més sufixos diminutius (nass-arr-in-et; mic-arr-in-oia, mic-arr-in-ona). Així mateix, el sufix -ot(a) sol afegir un matís despectiu, sobretot quan s'aplica en masculí a noms femenins, com a cuixarrot "cuixa massa grossa» (Moll I968: 220), amb -ot(a) afegit al sufix -arrola amb valor intensificador. La llengua antiga usava -ot(a) amb valor afectiu positiu, especialment en els derivats dels noms propis de persona (Joanot(a); Carlot(a)), en què històricament indicava «fill(a) de X». ${ }^{10}$ El sufix -ot(a) també pot adjuntar-se a bases adverbials (llunyot). Addicionalment, s'usen amb valor despectiu el sufix -astrela, que s'afegeix a bases nominals sense canviar el gènere (politicastrela), i el sufix força lexicalitzat -atxola, que normalment és augmentatiu (cavallatxo) tot i que pot tenir valor diminutiu (torratxa) i canviar el gènere de la base (com en la forma lexicalitzada velatxo «vela i verga de sobre mateix del trinquet»). Per al valencià, Sanchis Guarner (I993: 2II) recull l'ús limitat dels sufixos -utx(a) i -ol(a) amb valor despectiu en alguns mots concrets: casutxa, gentola.

Un cas especial d'augmentatiu és el grau superlatiu que formen les bases adjectivals amb el sufix -issim(a) (petitíssim (a)), el qual apareix amb la forma -èrrim(a) en alguns cultismes (Iibèrrim(a)). ${ }^{11}$ Com qualsevol altra forma apreciativa productiva, els superlatius no tenen entrada en els diccionaris, excepte els que prenen l'al.lomorf minoritari -èrim (a). ${ }^{12}$

A partir de bases verbals de la primera conjugació, s'han creat verbs amb sufixos augmentatius que denoten, sovint amb un matís despectiu, acció en quantitat més gran, intensa o freqüent, però que no són productius. Com en els diminutius, alguns dels sufixos augmentatius i despectius que apareixen amb bases nominals i adjectivals també ocorren amb bases verbals: -as(sar) (escridassar-se), -otej(ar) (besotejar, amargotejar). Altres, en canvi, només ocorren amb bases verbals en sentit augmentatiu, com

Io. L'ús afectiu positiu del sufix -ot(a) explica la sufixació doble amb el diminutiu -et(a) en formes lexicalitzades com ara parotet o xicotet(a), de pare i xic respectivament, en valencià, amb valor intensificador.

II. En el recompte del $D F$ (1996: XxxviII) esmentat a la nota 8, de les I6 379 ocurrències del lema petit, I20 corresponen a formes amb -issim (a); també s'hi comptabilitzen 2 ocurrències amb el prefix intensiu re- (repetit), que no és objecte d'estudi d'aquest treball pel seu caràcter prefixat.

I2. Tradicionalment, els superlatius no es consideraven part de la morfologia apreciativa, perquè normalment no tenen connotacions de valoració subjectiva sinó només de grandària. Rull (2004: 297), però, en recull usos expressius: "pujolíssim (un discurs pujolissim; Zèfir [llista de correu], 27-II-200I), benissim (Anem benissim) (Illes)». 
-on(ar) (empatxonar), el qual, com hem dit més amunt, té valor diminutiu amb bases nominals i adjectivals (cf. $-o ́(n a)$ : animaló, petitó(na)). ${ }^{13}$ Moll (1968: 238) afegeix per al balear -uny(ar) (cavunyar al DCVB: «cavar damunt damunt (Mall.)», no recollit al DIEC) i -eguis(sar) (esventeguissar al DCVB: «esventegassar-se», amb el sentit de "passar per molt de vent (Mall., Men.)", no recollit al DIEC; el DCVB recull, a més d'esventar "passar el vent intensament per un lloc», esventegar-se "aplegar molt de vent; anar molt pel vent (Mall.)».

Com s'ha comprovat, la divisió clàssica entre diminutius, per una banda, i augmentatius i despectius, per l'altra, és menys clara amb bases verbals que no pas amb bases nominals $i$ adjectivals, perquè sovint el matís iteratiu — i, per tant, en principi de tipus augmentatiu - que aquests sufixos aporten acaba remetent a una acció intensiva (augmentativa) o atenuada (diminutiva) segons l'acció verbal que modifica. Així, el sufix -ot(a) té bàsicament un valor augmentatiu (i despectiu) amb noms i adjectius (peuot, grandot(a)), però -otej(ar) aporta a la base verbal un matís merament despectiu (amargotejar) o un valor iteratiu amb matís augmentatiu (quantitat més gran a besotejar «besar repetides vegades») o diminutiu (quantitat més petita a menjotejar «fer menjades de no res i amb poca gana»). En conjunt, doncs, les formes intensives dels verbs es troben lexicalitzades, $\mathrm{i}$ per això figuren als diccionaris amb entrades independents; ${ }^{14}$ sovint hi apareixen amb diversos sufixos per a una mateixa base, sense especificar-ne el matís que aporten: al DIEC, per exemple, les entrades enllardonar i enllardissar remeten simplement a enllardar, mentre que les entrades menjussar, menjucar i menjuquejar remeten a un altre intensiu, menjotejar..$^{15}$

L'ús més habitual dels apreciatius en balear i en valencià fa que els reculls bibliogràfics més extensos apareguin referits a aquestes dues varietats (cf., p. ex., Moll I968).

En definitiva, els sufixos apreciatius productius i amb major extensió geogràfica del català són els diminutius -et(a) i, en menor mesura, -ó(na); els augmentatius -ot(a)

I3. El sufix -ot sempre concorre amb el sufix verbalitzador -ej(ar) (besotejar, ${ }^{*}$ besotar; amargotejar, ${ }^{*}$ amargotar), reforçant-ne encara més el caràcter lexicalitzat. Segons Cabré (1994: 64), l'únic sufix verbal intensiu amb valor augmentatiu és -as(sar).

I4. Moll (1968: 238) afirma al respecte: «Aquests infixos intensius no poden aplicar-se a qualsevol verb, sinó que s'apliquen només a uns radicals determinats; per ex. ningú no dirà plovussar per ploviscar, ni ningú dirà cantiscar per cantussar.»

I5. També al $D C V B$ i al $D D L C$ les formes intensives dels verbs tenen una entrada a part, a diferència de les formes apreciatives derivades de noms, adjectius i adverbis, que apareixen relacionades amb l'entrada del mot simple corresponent. 
i -às(sa) i el superlatiu -issim(a), i l'augmentatiu i despectiu -arro/a. Per a l'objectiu d'aquest treball, la discussió pren com a punt de referència aquests sufixos productius.

\section{C LA BASE LÈXICA DE LA SUFIXACIÓ APRECIATIVA}

Com és sabut, el procés de derivació del català es pot descriure de manera diferent, depenent de si es considera que la base lèxica a la qual s’adjunta un afix conté les terminacions flexives relacionades tradicionalment amb gènere en els elements nominals i amb la vocal temàtica en els verbs (casa de casar, menja de menjar) o no (cas-, menj-) (veg., p. ex., Cabré \& Rigau 1986: 25-28 i Cabré 2002: 733). Sigui quina sigui l'opció que es prengui, el que és interessant per a l'estudi actual és que la derivació apreciativa nominal moltes vegades té en compte la forma del mot base (que coincideix amb la base lèxica de la primera opció) per crear la forma apreciativa, un tipus de condicionament que és poc habitual en la derivació. Un cas ben estudiat és el del sufix diminutiu -(ec) itola en espanyol, que, entre altres peculiaritats, per norma general pren la forma -ecito/a si el mot base és monosil-làbic i acaba en consonant (sol, solecito; mar, marecita), però la forma -itola amb radicals de la mateixa forma si el mot base és bisil.làbic i acaba en $-o,-a$ flexives (solola, solitola; cara, carita) (veg., p. ex., NGLE: \$ 9.5).

Per al català, les primeres observacions sobre restriccions en la formació d'apreciatius segons la forma del mot base s'apunten en els treballs de Lloret (1996, 1998). En concret, s'observa que la presència de les terminacions nominals àtones atípiques - Vs sovint bloqueja la concurrència de sufixos apreciatius. Així, els mots acabats en $-s$ de radical permeten la formació de diminutius (piset), com també ho fan els que acaben en $-s$ pseudoflexiva (pseudoflexiva perquè són plurals inherents, com a tisoretes, o perquè hi apareix desclassada, com en el nom singular Atenes, que fa Atenetes). No la solen permetre, en canvi, aquells en què -s és part d'altres terminacions - $V s$ (cactus, ${ }^{*}$ cactet, virus, ${ }^{*}$ viret, d'acord amb les dades de Lloret 1996, 1998, que es revisaran a \$3.c).

\section{D LA CATEGORIA DE LA BASE LÈXICA DELS SUFIXOS APRECIATIUS}

En català, a més de les quatre categories esmentades a la bibliografia com a susceptibles de prendre sufixos apreciatius (noms, adjectius, verbs i adverbis), n'exis- 
teixen altres que en poden prendre amb sufixos productius, encara que amb un ús molt més limitat.

Per començar, els quantificadors numerals presenten formes lexicalitzades amb el diminutiu -et(a). Amb els cardinals, s'usen en termes musicals, com a doset, treset, cinquet, etc. Altres formes lexicalitzades remeten a monedes antigues, com ara quinzet o treset $(D C V B)$, o bé anomenen jocs, com el joc de cinquetes $(D C V B$, i cinqueta "cadascuna de les cinc pedres [...] per a jugar a cinquetes»), el treset o el joc de cartes anomenat popularment cinquet. El DCVB recull les expressions tots dosets («tots dos junts. [...] Totes dosetes s'estan al recó del foc») i nosaltres dosets («nosaltres dos plegats. Farem festa nosatros dosets»). Així mateix, els ordinals tenen formes lexicalitzades amb el sufix -et(a), com a quartet, tercet, quintet, sextet, etc. En l'ús col-loquial, s'usen els cardinals amb el diminutiu -et (a) per indicar «grup de $\mathrm{X}$ »: cinquet, siset, etc. A més dels usos lexicalitzats, els sufixos apreciatius poden afegir-se productivament a numerals quan funcionen com a noms, o bé dels nombres (per a deu el DCVB llista les formes deuet, deuot, deuarro i deùas) o bé de locucions (per a tres, el CTILC recull «tresét en ratlla»; per al col-lectiu parell, el $D C V B$ recull parellàs, parellot i tant el $D C V B$ com el CTILC, parellet) (veg. Annex, $\$$ I.a). ${ }^{16}$ També hi ha usos expressius del diminutiu i del superlatiu amb algun adjectiu ordinal, com primeret, primeríssim(a), ambdós al CTILC (veg. Annex, \$ I.b). I encara algun altre quantificador admet formes apreciatives: poquet(a), poquissim (a)...; especialment en locucions que admeten apreciatius en els elements que les conformen: una miqueta (de), una miquiua (de) (valencià, tortosí) (i 23 apreciatius més al $D C V B)$; un puntet (de); una goteta (de), etc. (veg. Annex, $\mathbb{\$}$ I.c).

Pel que fa als possessius, només el $D C V B$ reporta formes apreciatives, i tan sols per a meu en les expressions interjectives «fill mevet» $\mathrm{i}$ "Déu mevet» (Palma), ben vives a les Illes (veg. Annex, $\mathbb{S}_{3}$ ). Hi ha, però, usos expressius de possessius tònics diminutivitzats en construccions no interjectives, en posició postnominal i amb ús pronominal: meuet, teveta, seueta (veg. Annex, $\$$ 2.a). Els pronoms personals de tercera persona s'usen esporàdicament en diminutiu: elleta, elletes (veg. Annex, $\mathbb{\$} 2 . b$ ). Excepcionalment, apareixen usos expressius de demostratius diminutivitzats: aquetet, aquelletes (veg. Annex, \$ 2.c). ${ }^{17}$

16. D'ara endavant, es remet a l'Annex per a una mostra d'exemples de les formes apreciatives menys habituals localitzades.

17. En cerques per internet apareixen molt pocs exemples de diminutius amb demostratius. És l'únic cas en què, en les enquestes de validació, els informants van mostrar més aviat rebuig per les formes localitzades per 
L'expressió interjectiva Déun'hi do! presenta la forma habitual diminutiva Déun’hi doret!, i se'n poden crear amb altres interjeccions que contenen mots de la llengua que els admeten: Mareta meva! (al CTILC); Me cago en Deuet'; Perdonet! (veg. Annex, $\$ 3$ ).

Les preposicions, en principi, no tenen forma apreciativa; però les intransitives que en funció adverbial admeten sufixos apreciatius també en poden prendre quan s'usen com a preposicions. Així, la preposició intransitiva (a) prop (de) en funció adverbial pot afegir sufixos apreciatius amb valor expressiu i intensificador, com en $a$ propet (a propiu en valencià i tortosí) o a propissim, i també quan fa funció prepositiva: a propet de. La possibilitat de formar apreciatius amb adverbis - $\mathrm{i}$ amb preposicions intransitives- és bastant més reduïda que no pas amb noms i adjectius, i tan sols s'esdevé amb sufixos productius: llunyet (llunytet en valencià), llunyot, llunyissim; aviadet, aviadot, aviadissim; endinset; darrereta; enforet (a); encareta; aixinetes i aquinetes (mallorquí), etc. (veg. Annex, $\$ 4$ ).

En resum, de les categories susceptibles de forjar formes apreciatives, el català les admet productivament en el cas dels noms i dels adjectius; més limitadament amb alguns adverbis; ocasionalment amb alguns numerals i quantificadors, interjeccions, pronoms personals i possessius, i només excepcionalment amb demostratius. Les ocurrències amb verbs, en canvi, estan lexicalitzades.

\section{CREACIÓ LÈXICA AMB SUFIXOS APRECIATIUS}

\section{A ANTECEDENTS}

En el capítol que Rull (2004: $\$ 8$ ) dedica als augmentatius i diminutius, s'hi recullen nous usos i creacions dels apreciatius, en formes lexicalitzades i amb usos productius. Per a l'objectiu d'aquest treball, interessen sobretot les observacions que Rull suma a les de Lloret (1996, 1998) sobre l'ús productiu del sufix diminutiu -et(a) en noms masculins que acaben en $-a$, en femenins que acaben en $-o$ i en masculins que acaben en $-i$, que són terminacions atípiques del gènere corresponent i que, per norma general, apareixen en noms que no solen usar-se en forma apreciativa. Rull

internet. És pertinent observar que els demostratius ocupen la darrera posició en la jerarquia de Nieuwenheis (I985) presentada a $\$ 2 . a$. 
recull, per als dos primers casos, vacil-lació entre l'ús de les terminacions regulars de gènere ( $\varnothing$ de masculí, - $a$ de femení) al marge del gènere del mot base, tant si és masculí (problemet - problemeta) com si és femení (radieta - radiet); mentre que, per als masculins en $-i$, recull una única solució: la regularització cap a la marca de masculí $\varnothing$ (biquinet), tal com s'esdevé amb les formes de mots tradicionals amb terminació - $i$ (cf. bigotet). Cal destacar l'observació que Rull (2004: 300) fa sobre els casos amb vacil.lació:

Sembla que, en els mots acabats en - $a$ que són masculins, es poden deixar les dues possibilitats. Així, p. ex., al costat de temeta (Curs de sociolingüistica, vol. I, Alambor, 1990, pàg. I6) i problemeta, poden existir també les variants temet i problemet. [...] Els mots femenins en - o sembla que tendeixen a fer desaparèixer aquesta vocal i a posar-hi el morfema de femení - $a$ al final: moteta, radieta, etc., tot i que és possible sentir una altra solució (una radiet, lectura d'un missatge electrònic enviat per un vinarossenc al Cocodril Club, Ona Música, 8-4-200I).

La tendència que constata Rull cal dotar-la, però, d'una explicació formal, que relacioni les possibilitats que mostra la llengua amb l'estructura morfològica del mot i, més concretament, amb el caràcter morfològic que tenen les terminacions dels elements nominals, en línia amb els treballs de Lloret (1996, 1998). Per arribar a una generalització més àmplia i a una anàlisi formal satisfactòria, caldrà determinar, en primer lloc, quina naturalesa morfològica tenen les terminacions dels elements nominals en català $(\$ 3 . b)$ i quines formes prenen els derivats apreciatius de mots que no acaben en les terminacions regulars de flexió $(\$ 3 . c)$.

\section{B LES TERMINACIONS DELS NOMS I DELS ADJECTIUS EN CATALÀ}

En català, l'expressió de la categoria flexiva de nombre és regular: «[e]l plural dels noms i dels adjectius termina sempre en $\gg$ (Fabra 1956: $\$ 34$ ), o bé perquè l'afegeixen a la forma de singular corresponent (pals, cases, grans) — de vegades amb afegiment de vocal per desfer el contacte de sibilants (pisos; feliços, felices)—, o bé perquè ja acaben en "s» (la/les pols, ellels virus i fonèticament els acabats en -x o -ç: l'els indexs, la/les falçs).

L’expressió de la categoria flexiva de gènere (o classe flexiva, veg. $\$ 4$ ) és, en canvi, més complexa, perquè hi ha tota una sèrie de terminacions que tradicionalment s'hi han relacionat. Ara bé, només algunes són capaces de crear parelles oposades per gènere (morfològic) masculí/femení, amb dues terminacions $(\varnothing /-a,-o /-a,-e l-a,-w /-a)$ 
(Ia) o amb una única terminació $(\varnothing,-a,-e)(\mathrm{Ib})$, tant en adjectius com en noms amb referents sexuats i arrel comuna. (Les vocals en cursiva dels exemples de (I) es consideren epentètiques. $)^{18}$

(I)

$$
\begin{aligned}
& \text { a. }-\mathrm{o} /-\mathrm{a}:(\text { minoria }) \\
& \text {-e/-a: }(\text { bastants })^{19} \\
& \text {-w/-a:(pocs) }{ }^{20}
\end{aligned}
$$

b. $\varnothing: \quad$ (majoria)

-a: (minoria)

Adjectius

moreno/morena, flonjo/flonja

còmode/còmoda, culte/culta

europeu/europea, ateu/atea

gran, amable

belga, nòmada

rude, imberbe

\author{
Noms \\ gitano/gitana, monjo/monja \\ monge/monja \\ $\mathrm{reu} / \mathrm{rea}$, déu/dea ( $\sim$ deessa) \\ lladre, màrtir \\ guia, espia \\ cònjuge, conserge
}

Els adjectius i els noms amb parelles morfològiques només tenen el conjunt de terminacions de (I); en canvi, els noms amb un sol gènere mostren una gamma més àmplia de terminacions: a més de les esmentades, en un nombre molt reduït de noms apareixen $-o$ en femenins $i$, en masculins i femenins, $-i,-u,-s,-V s(2){ }^{21}$

I8. Només es tracten com a epentètiques les vocals $e$ que reparen grups de consonants que no segueixen la sonicitat decreixent que imposa l'estructura sil.làbica (veg. l'argumentació a Lloret 2002: $\$$ 5.4.I.2, 2013: $\$ 3$ ).

19. L'oposició $-e /-a$ és especialment pertinent per als dialectes occidentals (sense neutralització fonètica d'aquestes dues vocals), en què la distinció fins i tot s'imposa en mots tradicionalment invariables (rude/ruda, artistelartista, etc.). L'IEC considera admissible «la diferenciació fonètica entre el masculí i el femení del sufix -ista [...], pròpia dels parlars occidentals» (PEOLC: I6); l'AVL incorpora aquesta tendència en la norma de la llengua escrita $(G N V: 96)$.

20. Les terminacions de l'oposició - $w$ /-a i la terminació $-w$ de noms masculins amb un sol gènere (veg. (2)) sempre apareixen precedides de $e$ (ortogràficament, acabaments -eu i -ea; cf., per ex., Fabra I956: \$29). Mascaró (1986: 27, 97) suggereix la possibilitat d'analitzar aquests acabaments com a compostos d'un sufix derivatiu - $e$ (cf. mar-e-a, ur-e-a vs. mar-itim, úr-ic) seguit de la terminació flexiva - $w$ o $-a$. Per a l'objectiu d'aquest treball, és suficient referir-s'hi com a nominals amb terminacions $-w$ i $-a$.

2I. S'ignoren l'adjectiu culte isòsceles (cf. un probable isoscèlic) i noms com currículum (cf. curricular, curriculet), amb acabaments que s'interpretarien com les terminacions esporàdiques dels noms analitzades a $₫ 4$. Així mateix, s'ha descartat el nom i adjectiu invariable zulu (zulú al $D G L C$ ), sense derivats constatats per poder determinar el caràcter afixal o no de la vocal final (cf. bantu, bantuisme). 
(2)

$\begin{array}{lll}\varnothing: & \text { (majoria) } & \begin{array}{l}\text { Masculi } \\ \text { pis, armari }\end{array} \\ \text {-a: } & \text { (pocs) } & \text { problema, poema } \\ \text {-o: } & \text { (minoria) } & \text { suro, coco } \\ \text {-e: } & \text { (bastants) } & \text { cotxe, bisbe } \\ \text {-w: } & \text { (pocs) } & \text { ateneu, museu } \\ \text {-i, -u: } & \text { (esporàdics) } & \text { bigoti, whisky; sudoku } \\ \text {-s: } & \text { (esporàdics) } & \text { temps, socors } \\ \text {-Vs: } & \text { (esporàdics) } & \text { cutis, brindis } \\ & & \text { virus, eucaliptus } \\ & & \text { pàncrees, mecenes } \\ & & \text { cosmos, termos }\end{array}$

\begin{tabular}{|c|c|}
\hline $\begin{array}{l}\text { (minoria) } \\
\text { (majoria) } \\
\text { (esporàdics) } \\
\text { (pocs) }\end{array}$ & $\begin{array}{l}\text { Femení } \\
\text { carn, flor } \\
\text { casa, cama } \\
\text { moto, foto } \\
\text { piràmide, classe }\end{array}$ \\
\hline $\begin{array}{l}\text { (esporàdics) } \\
\text { (esporàdics) } \\
\text { (esporàdics) }\end{array}$ & $\begin{array}{l}\text { diòcesi, dosi; tribu } \\
\text { bilis, pelvis } \\
\text { dermis, glotis } \\
\text { venus } \\
\text { càries }\end{array}$ \\
\hline
\end{tabular}

En línia amb el raonament de Pérez Saldanya et alii (2004: $\$ 2.2 .2)$ i de Lloret (2013), es presumeix, d'entrada, que les terminacions que es troben directament relacionades amb el gènere gramatical són només les que poden crear oposicions; és a dir, a partir de les dades aportades: per al masculí, $\varnothing,-o,-e,-w(\varnothing$ com a primari, -o com a secundari i $-e,-w$ com a eventuals); per al femení, $-a, \varnothing(-a$ com a primari i $\varnothing$ com a secundari). En els masculins en $-a$ i els femenins en - $e$, que acaben sent bastant freqüents per les parelles d'una sola terminació (veg. (Ia)), - $a$ i $-e$ també poden ser considerades marques de gènere, encara que hi apareixen desclassades, o dit d'una altra manera, presents en mots que tenen el gènere contrari al que se'ls atribuiria per la terminació en els casos regulars (veg. l'argumentació a Lloret 2013: 265-267).

\section{C LES TERMINACIONS DELS SUFIXOS DERIVATIUS EN NOMS I ADJECTIUS}

Lloret (2013: $\$ 5$ ) adverteix que els sufixos derivatius nominals presenten menys terminacions que les que apareixen en les formes simples dels noms. La majoria de sufixos nominals i adjectivals acaben en les terminacions regulars, $\varnothing$ de masculí (petit-et, pastiss-er, cas-al) i -a de femení (petit-et-a, pastiss-er-a, fill-ad-a), i els que prenen altres terminacions mostren les mateixes limitacions de distribució que s'han detectat abans; és a dir, no prenen cap de les terminacions esporàdiques que exhibeixen les formes simples dels noms i presenten pocs casos amb altres terminacions. Concretament, s'hi mostren $\varnothing$ en femenins, - $a$ en masculins i - e en masculins i femenins (agr-or, geni-al, art-ist-a, terric-ol-a, full-atg-e, cant-air-e), i -o en la forma masculina del sufix apreciatiu 
-arro (noi-arr-o) (i els de menor extensió geogràfica apuntats a $\$ 2 . b$ ), que pren -a en les formes femenines corresponents (noi-arr-a).

Per tant, de les terminacions considerades marques de gènere a $\$ 3 . \mathrm{b}$ (per al masculí, $\varnothing,-o,-e,-w$; per al femení, $-a, \varnothing$, i les desclassades $-a$ de masculí $\mathrm{i}-e$ de femení), tan sols no hi ha exemples amb sufixos en el cas de la terminació $-w$ de masculí, la qual mostra una forta tendència a mantenir-se en els derivats apreciatius (europeuet, deuet) (3a) (veg. Annex, $\$$ 5.a) i, en menor mesura, en altres derivats (el CTILC recull, p. ex., deva - deua en altres textos literaris—, hebreua, ateneuista) (3b) (veg. Annex, $\$ 5 . b) .{ }^{22} \mathrm{Hi}$ pot haver influït tant la prosòdia, per la incorporació sil-làbica de $-w$ a l'arrel en la forma simple masculina, que a més evita el hiat en els derivats, com la morfologia, perquè $-w$ té una presència limitada com a terminació, ja que ni apareix en les parelles oposades per gènere amb una sola terminació ni en cap sufix derivatiu, però en canvi és habitual com a element de l'arrel (cf. garneu/garneua; hereu/hereua, hereva) (veg. Lloret 2013: 254, 256, 268-269).

(3) a. Formes apreciatives amb possible incorporació de $w$ a l'arrel $\operatorname{de-et}(\mathrm{a})$ - deu-et(a), europe-et(a) europeu-et(a), atene-et $~-$ ateneu-et

b. Altres derivats (amb incorporacions ocasionals de $w$ a l'arrel) de-a deu-a, dev-a (cf. de-ïtat); hebre-a hebreu-a (cf. hebra-ista); atene-ist-a ateneu-ista

En els derivats apreciatius, si la forma simple de partida presenta les marques de gènere (per al masculí, $\varnothing,-o,-e,-w$; per al femení, $-a, \varnothing$ ), la forma sufixada manté la categoria del gènere de la base, però mostra les marques regulars $(\varnothing$ en els masculins, $-a$ en els femenins) (4a, b), llevat dels sufixos apreciatius esmentats a $\$ 2 . b$, que presenten la marca secundària de masculí -o en la forma masculina a causa del sufix (4c). El sufix apreciatiu és, doncs, l'element que determina l'exponent del gènere: per al masculí, tots $\varnothing$, excepte uns quants que prenen la marca secundària - 0 ; per al femení, tots $-a$. Les vocals terminals, si n'hi ha, de les formes base no hi apareixen, com és habitual en la sufixació derivativa lèxica.

22. Altres mots presenten derivats amb vocal final incorporada a l'arrel i sense; p. ex., alumini fa alumini-et, alumini-ar, però alumin-osi (Mascaró 1986: 97). 
(4) a. Masculins $\varnothing,-o,-e,-w$; terminació $\varnothing$ en els apreciatius

$\varnothing$ : pis-et, pis-às; car-et, car-ot

-o: gitan-et, gitan-às; maqu-et, mac-ot

-e: cotx-et, cotx-às; comod-às, comod-ó

-w: atene-et $\sim$ ateneu-et; europe-et $\sim$ europeu-et

b. Femenins $-a, \varnothing$ (terminació $-a$ en els apreciatius)

-a: cas-et-a, cas-arr-a; car-et-a, car-ot-a; maqu-et-a, mac-ot-a; comod-ass-a, comod-on-a; de-et-a $\sim$ deu-et-a

$\varnothing$ : veu-et-a, veu-arr-a; carn-et-a

c. Masculins $\varnothing,-o,-e,-w$; terminació -o en els apreciatius -arro (i-el-lo, -etxo, -itxo, -utxo, - atxo)

$\varnothing,-o,-e,-w$ : peu-arr-o, flonj-arr-o, cotx-arr-o, europe-arr-o - europeu-arr-o

Cal comprovar ara què passa amb els noms i els adjectius que acaben en una terminació diferent de les esmentades. Per començar, els noms terminats en - $i$ (més freqüents en masculí) i en $-u$ (amb pocs exemples) segueixen la norma general: les formes apreciatives prenen les terminacions esperades segons el gènere de la base i el sufix apreciatiu, i la vocal final del mot base no hi apareix, tant si són paraules tradicionals com en manlleus recents (5) (veg. Annex, \$ 6).

(5) a. Masculins - $i$, - $u$; terminació $\varnothing$ en els apreciatius, llevat de -arro...

-i: bigot-et, bigot-às, bigot-ot, bigot-arr-o; whisk-et, whisk-às, whisk-arr-o

kiw-et, kiw-às, kiw-arr-o; biquin-et, biquin-às, biquin-arr-o

-u: sudok-et

b. Femenins $-i,-u$; terminació $-a$ en els apreciatius

-i: cris-et-a, cris-ass-a; dioces-et-a, dioces-ass-a, dioces-arr-a

-u: trib-et-a, trib-ass-a, trib-ot-a

També segueixen la norma general els noms i els adjectius d'una terminació amb parelles oposades per gènere i arrel comuna, els quals, com s'ha apuntat a $\$ 3 . b$, només presenten les terminacions $\varnothing,-a \mathrm{i}-e(6) .{ }^{23}$

23. Mots com espieta (masc. i fem.) són formes lexicalitzades del mot simple corresponent. 
(6) Masculins/Femenins $\varnothing,-a,-e$; terminacions $\varnothing /-a$ en els apreciatius, llevat de -arro/a...

$\varnothing: \quad$ (masc.) lladr(egu)-et, lladr(eg)-ot; grand-et, grand-arr-o

(fem.) lladr(egu)-et-a, lladr(eg)-ot-a; grand-et-a, grand-arr-a

-a: (masc.) artist-et, artist-às, artist-arr-o; belgu-et, belg-ot

(fem.) artist-et-a, artist-ass-a, artist-arr-a; belgu-et-a, belg-ot-a

-e: (masc.) ostatg-et; rud-ot, rud-às

(fem.) ostatg-et-a; rud-ot-a, rud-ass-a

Així mateix, els noms femenins en - $e$ amb un sol gènere (desclassats segons l'anàlisi proposada) segueixen la mateixa construcció (7).

(7) Femenins - $e$; terminació - $a$ en els apreciatius

-e (fem.): mar-et-a, mar-on-a, mar-ot-a; mar-ass-a (lexicalitzat)

piramid-et-a, piramid-ass-a, piramid-ot-a

En canvi, els noms masculins en - $a$ amb un sol gènere (desclassats segons l'anàlisi proposada) poden mostrar la vacil.lació que apuntava Rull (2004) (8). Majoritàriament, la vacil.lació apareix amb el sufix més productiu -et(a) i amb preferència per la construcció més tradicional amb terminació regular de masculí $\varnothing$ (veg. Annex, $\$ 7$ ). ${ }^{24}$

(8) Masculins $-a$

a. -et $\sim$-eta: dram-et $\sim$ dram-et-a; poem-et $\sim$ poem-et-a

problem-et $\sim$ problem-et-a; map-et $\sim$ map-et-a

b. Altres, $\varnothing: \quad$ dram-ot, dram-às; poem-ot, poem-às, poem-arr-o

(llevat de -arro...) problem-ot, problem-às, problem-arr-o; map-ot, map-às, map-arr-o

De la mateixa manera, els noms en -o amb un sol gènere femení mostren la predisposició a vacil.lar amb el sufix diminutiu -et(a) que observava Rull (2004), amb clara preferència per la construcció tradicional amb la terminació regular de femení -a (9a). Com abans, amb els altres sufixos apreciatius majoritàriament se segueix la norma general (terminació - a de femení, en aquest cas) (9b). (Veg. Annex, \$8.)

24. Al CTILC, p. ex., de 32 ocurrències de poema en diminutiu, 3I acaben en $\varnothing$ (poemet) i I en - $a$ (poemeta); per a drama, de 3 ocurrències diminutives, 2 acaben en $\varnothing$ (dramet) i i en - $a$ (drameta), mentre que les altres apreciatives sempre tenen $\varnothing$ (I dramot, 4 dramon(s)). 
MARIA-Rosa Lloret

La sufixació apreciativa del català: creacions lèxiques i implicacions morfològiques

(9) Femenins -o

a. -eta -et: mot-et-a $(\sim$ motor-et-a $) \sim$ mot-et; fot-et-a $\sim$ fot-et; radi-et-a $\sim$ radi-et

b. Altres, -a: mot-ass-a, mot-ot-a, mot-arr-a; fot-ass-a, fot-ot-a; radi-ass-a, radi-ot-a

És important ressaltar la diferència entre les formes masculines dels adjectius i dels noms amb parelles oposades per gènere i terminació única - $a$ (artista, p. ex.), que prenen $\varnothing$ amb el sufix diminutiu -et (cf. (6)), dels noms amb un sol gènere masculí i terminació - a (drama, p. ex.), que presenten vacil.lació - et - eta (cf. (8a)). La diferència es fonamenta en l'origen morfològic de les terminacions. Els diminutius de noms masculins en - $a$ d'un sol gènere poden terminar en - $a$ (drameta, al costat de dramet) perquè es tracta d'una falsa interpretació de la marca flexiva com a pseudofemení - $a$ (pseudofemení perquè el nom és pròpiament masculí, però presenta la marca regular de femení desclassada). En canvi, en els adjectius i els noms amb terminació única, - a no apareix en les formes apreciatives de masculí (un artistet i un artistàs, ambdós al CTILC) perquè-a apareix rectament en la forma femenina de la parella del mot base (una artista) i, pel caràcter invariable del mot base, la forma de masculí s'iguala a la de femení (veg. Lloret 20I3: 266). No es tracta, doncs, pròpiament d'una marca de pseudoflexió, i per això no apareix en la forma apreciativa masculina (*un artisteta, * un artistassa). D'altra banda, les alternances en noms femenins en -o d'un sol gènere (moteta - motet) demostren que, més que un arrossegament de la marca específica del mot base (que conduiria a *moteto), es tracta d'una falsa interpretació del gènere corresponent a causa de la terminació atípica de la marca pseudoflexiva: -o és una terminació esporàdica en noms femenins però és l'al-lomorf secundari de masculí i, per tant, pot ser falsament interpretada com a exponent del gènere masculí en mots com moto; però, en la forma diminutiva, el masculí només hi pot aparèixer amb la marca regular, $\varnothing$ (motet), perquè el sufix -et(a) només admet les terminacions regulars de flexió: $\varnothing,-a$ i $-s$ (i la combinació -es). Pel mateix motiu, els noms femenins en -e (desclassada) amb un sol gènere només admetien la terminació regular de femení - $a$ en els apreciatius (cf. (7)). Com es demostrarà, a favor d'aquesta interpretació hi juga el fet que la falsa interpretació de terminacions flexives només s'esdevé, a banda dels casos esmentats, en noms amb un sol gènere i terminació -s (i -es), en què la sibilant és interpretada com a marca pseudoflexiva de plural.

Els noms acabats en - $(V)$ s àtona es divideixen en dos grups: els que presenten terminacions que poden ser interpretades com a marques de pseudoflexió perquè co- 
incideixen formalment amb les terminacions regulars dels plurals —amb -s de plural (temp-s, Dolor-s) o amb -es de femení i plural (mecen-es, Eli-es) — i els que presenten altres terminacions (vir-us, clitor-is, term-os). Només en el primer cas la terminació del mot base pot aparèixer en la terminació de les formes apreciatives corresponents, alternant amb altres solucions. En el cas més habitual de formes afectives de noms personals masculins en -es (Elies, Carles, Hèrcules), alguns sempre mostren terminació -es (IOa), mentre que altres presenten vacil.lació entre la presència o no (forma tradicional) de la terminació susceptible de ser interpretada com a pseudoflexiva (Iob), especialment amb el sufix -et(a) (cf. (8a)). I encara n'hi ha d'altres que, amb usos no personals, segueixen la norma general de la sufixació apreciativa (Ioc) (cf. (6)). Els pocs - $\mathrm{i}$ poc freqüents- noms comuns masculins amb terminació àtona -es (àlies, atles, bòrees, càrdies, galimaties, mecenes, pàncrees) s'usen molt ocasionalment en forma apreciativa, però quan ho fan opten per acabar en la terminació pseudoflexiva -es (Ioa'). (Veg. Annex, $\$$ 9.) ${ }^{25}$

(Io) Masculins -es

a. Eli-et-es, Eli-ot-es; Mati-et-es, Mati-ot-es

a'. mecen-et-es, mecen-ass-es; galimati-et-es

b. Carl-et $\sim$ Carl-et-es ( $\sim$ Carl-et-s), Carl-ot $\left(\sim\right.$ Carl-ot-s) ${ }^{26}$ (cf. carl-isme)

c. hercul-et (cf. hercul-à); socrat-et (cf. socràt-ic); xenofont-et (cf. xenofont-ista)

Els noms comuns amb terminació -s són comptats (masculins com temp-s, socor-s; femenins com bili-s, pelvi-s, pleb-s). El d'ús més freqüent en forma apreciativa és el masculí temps, amb -s susceptible de ser interpretada com a pseudoplural. Quan indica "durada», temps (IIa) té el derivat lèxic tempsutl-da, amb -s incorporada a l'arrel, al costat d'altres que no la hi incorporen (temporal, temporada), i habitualment també la incorpora en les formes apreciatives (tempset, tempsot), encara que en algunes ocurrències apareix sense -s (tempet, temparro) o amb -s pseudoflexiva en la terminació (tempets) (veg. Annex, $\$$ Io.a). Temps en el sentit de «estat de l'atmosfera» (IIb) no té -s en els derivats lèxics (temporal, tempura); però prefereix les formes apreciatives amb

25. No s'ha trobat cap exemple per internet ni al CTILC de nom comú masculí en -es amb ús apreciatiu. Els exemples són de Lloret (1996) i Rull (2007), comprovats amb els nostres informants (veg. n. 30). 26. Per a les formes Carlets i Carlots, veg. (I8b). 
-s incorporada a l'arrel (tempset, tempsot), encara que també apareix sense -s en alguns casos (tempot, temparrot) (veg. Annex, $\mathbb{\$}$ Io.b). ${ }^{27}$

(II) Masculins -s, noms comuns

a. temps (cf. temps-ut/-da; tempor-al, tempor-ada)

temps-et $\sim$ temp-et $(\sim$ temp-et-s), temps-ot, temp-arr-o

b. temps (cf. temp-oral, temp-ura)

temps-et, temps-ot $\sim$ temp-ot, temp-arr-ot

Els noms personals femenins en -s (Dolor-s, Àngel-s) tenen formes apreciatives que mai no incorporen la sibilant a l'arrel, amb tres terminacions possibles: terminació regularitzada - $a$ de femení, amb terminació -s de pseudoplural (Doloretes, Angeletes) o no (Doloreta, Angeleta), o terminació secundària de femení $\varnothing$ amb presència final de $-s$ de pseudoplural (Dolorets, Angelets), (I2a) (veg. Annex, $\$$ ir.a). ${ }^{28}$ Convé destacar que la darrera solució implica excepcionalment el manteniment de la terminació secundària de femení $\varnothing$ en l'apreciatiu, la qual cosa no s'esdevé en els noms comuns (cf. carn, carneta). Com observa Bermúdez-Otero (2006) amb relació a una asimetria similar que presenten els noms propis Ángeles i Dolores en espanyol, la causa deu estar relacionada amb el fet que són noms personals femenins que s'han format a partir de noms comuns típicament masculins, amb terminació $\varnothing$ regular de masculí (els àngels, els/les dolors). Les solucions apuntades per als femenins en $-s$ s'adiuen amb les formes que presenta el nom propi masculí Carles quan la vocal $e$ de la terminació -es s'interpreta en termes d'epèntesi $\left({ }^{*} \mathrm{Carl}-\mathrm{s}\right)$ (veg. Lloret 1996); en aquest cas, com és previsible, les formes apreciatives mostren terminació regular de masculí $\varnothing$, amb -s de pseudoplural afegida (Carlets, Carlots) o no (Carlet, Carlot), (I2b) (veg. Annex, $\$$ iг.b i $\$$ 9.b). ${ }^{29}$ El mateix s'esdevé amb atles, que pot fer atl-et o atl-et-s (cf. (II)). ${ }^{30}$

27. No s'ha trobat cap exemple de formes apreciatives d'altres noms comuns amb terminació -s.

28. Doloretes és l'única forma recollida al $D C V B$ (s.v. dolor). Angeleta també pot ser diminutiu d'Àngela. Carlets).

29. Carlet i Carlot apareixen documentats a l'època medieval (veg., p. ex., $D C V B$, on també es recull

30. No s'ha trobat cap exemple de formes apreciatives d'atles ni al CTILC ni per internet (els que hi apareixen d'atlet (s) són formes en masculí plural d'atleta). Els informants utilitzats per validar els exemples han admès, però, atlet $\mathrm{i}$ atlets com a possibles diminutius d'atles, amb preferència per atlets. 
(I2) a. Femenins $-s$, noms personals

Dolor-et-a Dolor-et-es Dolor-et-s; Angel-et-a Angel-et-es Angel-et-s

b. Masculins $-s$, noms personals

Carl-et Carl-et-s, Carl-ot Carl-ot-s

Les formes apreciatives dels noms geogràfics en -es (Banyol-es, Aten-es), que solen interpretar-se com a femenins per la presència de - $a$ (ortogràficament $e$ en la terminació -es), a més de tenir marca regular de femení - $a$, presenten $-s$ de pseudoplural (Iza) (veg. Annex, $\$$ I2.a). La terminació $-s$ també apareix en els derivats apreciatius dels noms geogràfics amb terminació de pseudoplural -s (Cambril-s, Areny-s), que solen interpretar-se com a masculins (I3b) (veg. Annex, $\$$ I2.b).

(13) Noms geogràfics -es, $-s$

a. (fem.) Banyol-et-es; Aten-et-es

b. (masc.) Cambril-et-s; Areny-et-s

Els noms acabats en altres segments àtons - $V s(-i s,-u s,-o s)$ no es relacionen amb marques de flexió perquè no coincideixen amb les terminacions regulars dels plurals i, per això, els derivats apreciatius presenten les marques regulars de gènere i nombre, sense la terminació del mot base (I4a) (cf. (4), (5), (7)). Hi ha, però, la tendència recent a mantenir la terminació del mot base en l'arrel de la forma apreciativa (viruset, venuseta) (I4b) (cf. (4) i (II)). Els exemples són en conjunt limitats (n’hi ha pocs i són mots poc usats, especialment en forma apreciativa: cutis, glotis, dermis, clitoris; virus, cactus, eucaliptus, venus; cosmos, termos, albatros...); però mostren les dues solucions esmentades: la construcció més tradicional (I4a) i la innovadora (I4b) (veg. Annex, \$rza, b, respectivament). ${ }^{31}$

3I. Bermúdez-Otero (2006: 30I) apunta que en espanyol la incorporació de -us, -is a l'arrel de les formes apreciatives és molt habitual en contextos informals (virus-it-o, virus-ot-e, virus-ón; brindis-it-o). No ho és tant, però, en català, i és d'incorporació recent (en cerca a Google realitzada el 2005, no va aparèixer cap coincidència del tipus viruset, venuseta). No es discuteix aquí la possibilitat que en català s'hagin creat per influència de l'espanyol; interessen només com a novetats lèxiques. 
(I4) Terminacions -is,-us, -os

a. -is: (masc.) clitor-et (cf. clitor-al)

-us: (masc.) eucalipt-et (cf. eucalipt-ol)

-os: (masc.) term-ot (cf. term-al)

b. -us: (masc.) virus-et (cf. vír-ic); eucaliptus-et

(fem.) venus-et-a (cf. ven-eri)

A partir dels exemples recollits, es pot concloure que els parlants formen els derivats apreciatius de manera diferent, atenent, però, els factors gramaticals següents: o bé segueixen la norma general de mostrar la terminació regular del gènere i del nombre que els pertoca, $\varnothing$ de masculí, - $a$ de femení i -s de plural —excepte en els pocs sufixos que tenen -o en el masculí (-arro, -etxo...) —; o bé, quan les terminacions atípiques poden ser falsament interpretades com a marques pseudoflexives, poden fer aparèixer les marques regulars del pseudogènere i/o del pseudoplural en les terminacions de les formes apreciatives corresponents, especialment en el cas del diminutiu -et(a) (poem-et-a, mot-et, temp-et-s, Eli-et-es, Carl-et-s, Dolor-et-s Dolor-et-es, Cambril-et-s, Banyolet-es). Ocasionalment, algunes terminacions del mot base (-w, $-s,-u s)$ poden incorporar-se a l'arrel (europeu-et(a), temps-et, virus-et).

\section{D LES TERMINACIONS DELS APRECIATIUS D'ALTRES CATEGORIES}

En els elements presentats a $\$$ 2.d que comparteixen la categoria nominal de noms i adjectius (això és, quantificadors, pronoms personals, possessius i demostratius), les terminacions de les formes apreciatives corresponents segueixen la norma general: $\varnothing$ de masculí (-o en determinats sufixos), -a de femení i $-s$ de plural: poquet(a), poquiu(a), deuarro, elletes, seveta, aquelletes, etc.

Així mateix, en els adverbis i en les preposicions intransitives il.lustrats a $\$$ 2.d, que són elements invariables, les formes apreciatives presenten, en general, $-a$ si la base acaba en - a i $\varnothing$ en els altres casos i amb -issim: propet, propissim; llunyet, llunyot, llunyissim; enforeta, etc. La tendència clàssica del balear consisteix a usar-los amb la forma no marcada en $\varnothing$ a -et $\mathrm{i}$-ot, amb valor intensificador: endinset «fer-se molt endins», enforet «molt enfora», enrerot "molt enrere» (Alcover 200I: I22, 30I). En mallorquí són prou esteses les formes en -es aquinetes i aixinetes ( $D C V B$; Moll 1985: I90, I98), derivades de les formes pseudoflexionades aquines i aixines, respectivament. 
De fet, l'ús pseudoflexionat dels adverbis aqui i així (i d'altres), amb afixos apreciatius o no, és habitual en altres dialectes: aquina, aquineta, aquines, aquinetes, aquins, aquinos, suaquinos, suaquinetes; aixina, aixines, aixinetes, aixintes, aixins, aixis, aixinos, aixinses, suixinos, etc. $(D C V B)$.

En les interjeccions i en les locucions, les formes apreciatives adopten la terminació regular de la categoria flexiva nominal del mot al qual s'adjunten els sufixos (Déu meuet:; Mareta meva!; Perdonet!; a gustet, una miqueta de), o bé la no marcada $(\varnothing)$ en mots d'altres categories (Déu n'hi doret.) (veg. \$2.d).

En conjunt, l'aportació més significativa que fan aquestes dades té a veure amb el tractament gramatical de les terminacions nominals, ja que si apareixen en formes apreciatives de mots invariables qüestionen la seva identificació com a marques de flexió.

\section{EL CARÀCTER GRAMATICAL DE LES TERMINACIONS NOMINALS A LA LLUM DE LA SUFIXACIÓ APRECIATIVA}

Alguns autors (p. ex., Harris 1985, per a l'espanyol, i Mascaró 1985, per al català) interpreten el fet que elements invariables com els adverbis presentin terminacions típicament flexives en les formes apreciatives com a indici per qüestionar la relació entre les terminacions nominals i la categoria de gènere (morfològic) corresponent, tractant-les, totes, com a marcadors de paraula o elements terminals. L'alternativa és analitzar aquests casos com a falsament interpretats amb marques flexives i, per tant, susceptibles d'ocórrer-hi, sense valor purament flexiu. Més decisiu és diferenciar les terminacions relacionades amb gènere (morfològic), entès com a classe flexiva, dels acabaments atípics i esporàdics, que no són pròpiament flexius, en línia amb els treballs iniciats per Viaplana (199i) (veg. Lloret 2013).

Des d'aquest punt de vista, una primera conclusió que es pot extreure atenent al fet que les úniques terminacions que adopten els derivats amb sufixos apreciatius són, rectament o per falsa interpretació de la terminació del mot base, $\varnothing,-a$, -s (i la combinació -es) i algun cas de -o en masculins (-arro, -etxo, etc.) és que només les terminacions $\varnothing,-a,-o,-s(\mathrm{i}-e s,-o s)$ són pròpiament flexives (I5a). Amb tot, des d'una perspectiva més àmplia i malgrat no haver-hi cap sufix apreciatiu en -e, el fet que alguns sufixos derivatius lèxics prenguin - $e$ en formes bàsicament masculines (-atge, -aire, etc.) així com la capacitat de -e per diferenciar — especialment en els dialectes 
occidentals - els masculins en parelles masculí/femení $(-e /-a$, a més de $\varnothing /-a$ i $-o /-a)$ fa que es pugui eixamplar l'inventari de les marques relacionades amb masculí, com a mínim amb la inclusió de -e i probablement també de $-w$, en recessió, per la sola habilitat de diferenciar els masculins en algunes parelles $(-w /-a)$ ( $15 \mathrm{~b})$.

(I5) Terminacions flexives del català

a. -s (plural); Ø (masc. i alguns fem.); -a (fem. i alguns masc.); -o (masc.)

b. -s (plural); Ø (masc. i alguns fem.); -a (fem. i alguns masc.); -o (masc.); -e (-w ) (masc.)

Arribats a aquest punt, es pot afirmar que les dues alternatives anteriors són viables, depenent del criteri que es prioritzi. En cap cas, però, es poden igualar les terminacions flexives apuntades a (I5) amb la resta d'acabaments, del tot idiosincràtics, sense capacitat per distingir una de les formes de parelles morfològiques masculí/femení i sense possibilitat d'aparèixer com a terminacions de formes sufixades. ${ }^{32}$

\section{CONCLUSIONS}

La situació excepcional de la morfologia apreciativa a causa de la informació limitada que, en general, contenen les gramàtiques i els diccionaris sobre aquest aspecte i per l'ús majoritari d'aquestes formes en contextos familiars i informals fa que la creativitat dels parlants no es vegi restringida per normatives, per la qual cosa afloren solucions imaginatives i variables. Els exemples que s'han resseguit mostren que, en el llenguatge informal, les limitacions a connotacions expressives dels mots són bastant reduïdes — hi ha una amplíssima gamma de situacions que permet l'ús de formes apreciatives de diferents categories-; però que, en canvi, l'estructura morfològica dels apreciatius té uns condicionaments gramaticals clars, que alhora ajuden a (re)interpretar altres elements de la llengua. Així, l'estudi de la formació apreciativa, des de l'angle de la creació lèxica, ha permès constatar que hi ha variació formal, però dins

32. A l'hora de tancar aquest estudi, s'ha tingut coneixement del treball d'Ambadiang i Camus Bergareche (20I2) sobre la formació de diminutius en espanyol, en què, a partir de la distribució dels al·lomorfs -ito/a, -citola i -ecitola i de la inclusió o no de les terminacions dels mots base en l'arrel dels diminutius corresponents, també arriben a la conclusió que cal diferenciar les terminacions que són marques morfològiques rellevants —en paraules seves - per a la flexió (per a l'espanyol, $-s,-o,-a$ i secundàriament $-e$, i les combinacions -os, -as) de les que no ho són $(-i,-u,-i s,-u s,-e s)$. 
d'uns límits fixats per la gramàtica; i, des de l'angle de la morfologia flexiva, ha permès fer una intersecció entre el conjunt de totes les terminacions nominals i el conjunt de les terminacions pròpies dels sufixos apreciatius (i lèxics), per delimitar — des d'aquest punt de vista, almenys - quines són les veritables terminacions flexives nominals del català.

Maria-Rosa LLORET

Universitat de Barcelona

mrosa.lloret@ub.edu

\section{REFERÈNCIES BIBLIOGRÀFIQUES}

Alcover, A. M. (200I) Mostra de diccionari mallorquí, Barcelona, Abadia de Montserrat. Ambadiang, T. \& B. Camus Bergareche (20I2) «Morfofonología de la formación de diminutivos en español: ¿reglas morfológicas o restriccions fonológicas?», dins A. Fábregas, E. Felíu, J. Martín \& J. Pazó (eds.), Los limites de la morfología. Estudios ofrecidos a Soledad Varela Ortega, Madrid, Universidad Autónoma de Madrid, pp. 55-77.

Bermúdez-Otero, R. (2006) «Morphological structure and phonological domains in Spanish denominal derivation», dins F. Martínez-Gil \& S. Colina (eds.), Optimality-Theoretic Studies in Spanish Phonology, Amsterdam/Filadèlfia, John Benjamins, pp. 278-3II.

Bernal, E. (2OI2) «The translations of fictive orality and diastratic variation: appreciative derivation", dins J. Brumme \& A. Espunya (eds.), The Translation of Fictive Dialogue, Amsterdam / Nova York, Rodopi, pp. I55-I64.

CAbré, M. T. (1994) A l'entorn de la paraula, 2 vols. València, Universitat de València.

- (2002) "La derivació», dins J. Solà, M.-R. Lloret, J. Mascaró \& M. Pérez Saldanya (dirs.), Gramàtica del català contemporani, vol. I, Barcelona, Empúries, pp. 73I-774.

Cabré, M. T. \& G. Rigau (1986) Lexicologia i semàntica, Barcelona, Enciclopèdia Catalana.

CTILC = InstituT D’Estudis Catalans, Corpus textual informatitzat de la llengua catalana. [En línia <ctilc.iec.cat/>.]

$D C V B=$ A. M. Alcover \& F. de B. Moll (I930-1962) Diccionaricatalà-valencià-balear, Io vol., Palma de Mallorca, Impremta de Mn. Alcover / Gràfiques Miramar 
(segons els volums; 2a ed. del vol. 2, 1964; del vol. I, Palma de Mallorca, Moll, 1968.) [En línia: $<$ dcvb.iecat.net>.]

DDLC = Institut D'Estudis Catalans, Diccionari descriptiu de la llengua catalana .

[En línia: adcc.iec.cat/ddlc>.]

$D F=$ J. Rafel i Fontanals, dir. (1996) Diccionari de freqüències I. Llengua no literària, Barcelona, Institut d'Estudis Catalans.

$D G L C=$ P. FABRA (1932), Diccionarigeneral de la llengua catalana, Barcelona, Llibreria

Catalònia. [Cito per la I7a ed. Barcelona, EDHASA, 1983.]

DIEC = InstituT D'Estudis Catalans (2007) Diccionari de la llengua catalana, $2 \mathrm{a}$ ed., Barcelona, Edicions 62 / Enciclopèdia Catalana. [En línia: <dlc.iec.cat>]

Dressler, W. U. \& L. Merlini Barbaresi (1994) Morphopragmatics. Diminutives and

Intensifiers in Italian, German, and Other Languages, Berlín, Mouton De Gruyter.

FaBra, P. (1956) Gramàtica catalana, Barcelona, Teide. [Cito per la 9a ed., 1979.]

GNV = ACAdÈmia Valenciana de la Llengua (2006) Gramàtica normativa valencia$n a$, València, Acadèmia Valenciana de la Llengua. [En línia: <www.avl.gva.es/ $\mathrm{PDF} / \mathrm{GNV} \cdot \mathrm{pdf}>]$

Harris, J. W. (1985) «Spanish word markers», dins F. H. Jr. Nuessel (ed.), Current Issues in Spanish Phonology and Morphology, Bloomington, Indiana University Linguistics Club, pp. 33-54.

Lloret, M.-R. (1996) «Els diminutius i les marques de gènere», dins Estudis de lingüística i filologia oferts a Antoni M. Badia i Margarit, vol. 3, Barcelona, Departament de Filologia Catalana, Universitat de Barcelona / Abadia de Montserrat, pp. 63-76.

- (1998) "Sobre l'estructura morfològica dels noms en català i en castellà», dins G. Ruffino (ed.), Atti del XXI Congresso Internazionale di Linguistica e Filologia Romanza, vol. 2, Tübingen, Niemeyer, pp. 557-566.

— (2002) «Estructura sil-làbica», dins J. Solà, M.-R. Lloret, J. Mascaró \& M. Pérez Saldanya (dirs.), Gramàtica del català contemporani, vol. I, Barcelona, Empúries, pp. 195-249.

- (2013) «Diferències en les terminacions flexives dels elements nominals», dins E. Clua \& M.-R. Lloret (eds.), Qüestions de morfologia flexiva i lèxica del català. Volum d'homenatge a Joaquim Viaplana, Alacant, Institut Interuniversitari de Filologia Valenciana, pp. 245-278.

Mascaró, J. (1985) "Catalan nominal markers and vowel insertion», Working Papers in Linguistics, vol. 7, Cornell, Cornell University, pp. I62-175. 
- (1986) Morfologia, Barcelona, Enciclopèdia Catalana.

Moll, F. de B. (1968) Gramàtica catalana referida especialment a les Illes Balears, Palma de Mallorca, Raixa. [Cito per la 9a ed., 1985.]

$N G L E=$ Real Academia Española \& Asociación de Academias de la Lengua Española (2009) Nueva gramática de la lengua española. Morfología, Sintaxis I, Madrid, Espasa.

PEOLC = Institut D'Estudis Catalans (1999) Proposta per a un estàndard oral de la llengua catalana, I. Fonètica (3a ed.), Barcelona, Institut d'Estudis Catalans. [Primera ed., 1996, dins Documents de la Secció Filològica, II, Barcelona, Institut d'Estudis Catalans, pp. IOI-II8. En línia: <publicacions.iec.cat/repository/ $\mathrm{pdf} / 00000062 / 00000072 . \mathrm{pdf} />$.]

Pérez Saldanya, M., M. Sifre Gómez \& J. Todolí Cervera (2004) Morfologia catalana, Barcelona, Universitat Oberta de Catalunya.

Rull, X. (2004) La formació dels mots. Qüestions de normativa, Vic, Eumo.

— (2007) «Els substantius d'acció i efecte en català», tesi doctoral, Universitat Rovira

i Virgili. [En línia: <www.tdx.cat/handle/ı0803/8777>.]

Sanchis Guarner, M. (1993) Gramàtica valenciana, ed. a cura d'A. Ferrando, Barcelona, Alta Fulla.

Scalise, S. (1988) "The notion of "head" in morphology», dins G. Booij \& J. van Marle (eds.), Yearbook of Morphology, Dordrecht, Foris, pp. 229-245.

VenY, J. (1983) Els parlars catalans, 4a ed., Palma de Mallorca, Moll.

Viaplana, J. (199I) «Sobre la flexió nominal en català», dins Estudis de llengua i literatura catalanes, vol. 23, Barcelona, Abadia de Montserrat, pp. 235-264.

\section{ANNEX}

\section{NUMERALS I QUANTIFICADORS}

a. Deuet (sempre anava a comprar amb Io cèntims)» (renom recollit a Linyola) [www.onomastica.cat/sites/onomastica.cat/files/Io_nabau.PDF] «vui $\mathrm{k}$ treguis un deuàs a la sele» (29-05-2008) [www.fotolog.com/poetasunidas/43044098/] "es mereix un deuarro per la fotografia» (OI-I2-2OI2) 
[forum3xl.foroactivo.com/t55pi35-la-pelli-de-la-setmana] "collia un parellet de figuetes» [CTILC: Oliver, M.-A. (1972)]

b. Lo primeret que fá, ¡sapiaho, richs! Es donar á los pòbres tot cuant té» [CTILC: Altet i Ruate, B. (1855)]

«no pot comprendre la convenció representada per un primeríssim pla» [CTILC: Porter i Moix, M. (1962)]

c. " «posa poqueta sal als menjars» (I9-IO-20I2) [farmaciacodinachplanas.cat/consultes-2/] «està tocant una miqueta de Beethoven» [CTILC: Segarra, J. M. de (1964)]

\section{POSSESSIUS, PERSONALS I DEMOSTRATIUS}

a. Qui la ballarà, seueta serà» (cançoner popular) [books.google.es/books?id=MoyexEklOGwC] «El meuet no vol callar ni en breçol ni en cadira» (cançoner popular) [books.google.es/books?id=ejfGMeLnki4C] «Saps q tens ca teveta de bcn, un quarto per compartir» (08-09-2008) [www.fotolog.com/horesbruixesss/17386178/]

b. $\quad$ «La reservá sens crim en tot elleta» (P. Serafí) [books.google.es/books?id=qWugz--n8sYC] «mirala que mona tota elleta?» (17-05-2008) [www.fotolog.com/mariina_7_93/58139878/] «amb les fotitos del dissabtet que monetes elletes» (09-I2-2008) [www.fotolog.com/dreeaaa/43889184/]

c. «jo tambe trobo a faltar aquelletes nits» (24-OI-2008) [www.fotolog.com/gemma_light7/22349402/] "Ja que el capullo aquetet no renova renovo jo!» (28-10-2007) [www.fotolog.com/segueu_arran/3261025I/] 


\section{EXPRESSIONS INTERJECTIVES}

"Déu menet! (3-0). El Getafe goleja el Reial Mallorca» (o6-I2-20IO)

[dbalears.cat/actualitat/esports/deu-meuet-3-o.html]

"-Ai, mareta meva!... Una dona al llit del meu marit!»

[CTILC: Porta i Rosés, V. (1986)]

"Déu n’hi doret! Quins regals que ens van portar» (30-04-2009)

[setmanacultural2007.blogspot.com.es/2009/04/deu-nhi-doret.html]

"va exclamar: - Me c---en Deuet.» (M. Torres)

[www.rodamots.com/mot_cerca_resultat.asp?nm=2539]

«Ho provaré amb un llensolet (perdonet que no tinc la c trencada en aquest teclat)» (I7-08-20I2)

[forum.socpetit.cat/viewtopic.php?t=30863]

\section{ADVERBIS I PREPOSICIONS}

a. «Mentre els hi deia, així, ben a propet com estaven»

[CTILC: Ferran de Pol, L. (1954)]

"Cal partir, que Sort encara es enforet» (A. M. Alcover)

[personales.ya.com/muntanya/textos/alcoverr.htm]

«avui, que estàs enforeta i que t'he notat aquest punt desanimat a la veu» (2IIO-20II)

[relatsencatala.cat/relat/lart-de-fer-etern-un-instant/I034320]

"Des de Son Sardina, la Colònia de Sant Pere és enforissim» (03-08-2005)

[lorucdeformentor.blogspot.com/2005/o8/aix-s-enforssim.html]

"no sabeu com em vindria de bé... però em pilla llunytet...» (9-II-2OII)

[caes.facebook.com/permalink.php?story_fbid=I56457077785951\&id=I51526691612323]

"Cavar endinset, fa fugir es fred» (refrany, Mallorca)

[books.google.es/books?isbn $=842976545 \mathrm{X}$ ]

«no va tenir, ni de lluny, el protagonisme exclusiu que li dona en Balutxo i ben

darrereta, els seus corregilionaris» (fa més de 3 anys)

[dbalears.cat/sfComment/commentPage/id/I7993/model/Noticia/page/2]

«I aquest tremolor som a sentdemà i em dura encareta» (29-09-2006) 
[z.blog.cat/2006/og/29/pels_atolls/]

"I quan no pots més, ni aixinetes més, tirar tovallola» (G. Florit i Ferrer)

[www.escriptors.cat/autors/floritg/pagina.php?id_text=3143]

"que enlloc del món pot estar/ més bé, [...] / que aquinetes té menjar/» [www.eeif.es/significados/a/Andreu\%2oMinguet,\%2oLluis.html]

b. «tot tenint-nos a propet del cor amb aquella escalforeta»

[CTILC: Millet i Pagès, L. (1917)]

«És a propissim de l'estació dels Catalans» (II-I2-20IO)

[ossul.blogspot.com.es/2010/12/dos-nous-restaurants-de-rubi-on.html]

«l'havien de traginar tota d'un pou o sínia bastant enforet de les cases» (R. Ginard i Bauçà)

[books.google.es/books?isbn=8498833906]

"allà deçà, endinset de sa carretera» (02-1990)

[ibdigital.uib.es/greenstone/collect/premsaForanaSantaMariaCami/import/

Coanegra/1990/Coanegra_1990_meso2_noo68.pdf]

"Es gayre llunyet d'aquí?"»

[CTILC: Oller, N. (I882)]

\section{MASCULINS EN -W}

a. «la curiositat d'un europeuet com jo» (19-04-2006)

[desdesants.blog.cat/page/55/]

"lluint els cabells rossos com un deuet infant»

[CTILC: Moyà i Gilabert, L. (1969)]

«estem refromant l'Ateneuet per tal d'encarar una temporada més» (05-08-20II) [apvallcarca.wordpress.com/20II/o8/o5/a-lagost-feina-i-mes-feina/]

b. "Que l'Olimp es poblat de déus i deves»

[CTILC: Maragall, J. (I913)]

"com la deua meua i del mar»

[Casasses, E. (1991) La cosa aquella, Barcelona, Empúries, p. 6I]

«en una llengua primitiva anterior [...], que si no es la hebreua'n pot ser una branca»

[CTILC: Vidal i Rosich, C. (I906)] 
«El Betes era un ateneuista de tota la vida»

[CTILC: Romeu i Sabater, A. (1959)]

\section{NOMS MASCULINS I FEMENINS EN $-I,-U$}

a. El fet de veure-la sol, amb un güisquet i sense nens,» (23-02-2006)

[ignasisorolla.blogspot.com.es/2006/o2/la-isla.html]

«jo tambévull anar a scothland a posar-me fins el cul de güiscarro del bo!!!!!!!!!!!!!!!»

(O2-04-2010)

[caotisme-incessant.blogspot.com.es/2010/04/scottish-passover.html]

«qui eres tu i que has fet amb el kiwet?» (17-08-20I2)

[https://twitter.com/Oriol_Oller/status/236523577602613248]

«és q sudava d'anar amb biquinet i q em sortís una teta allà nedant!» (I7-IO-2008)

[www.fotolog.com/esteldenit/38361934/]

«vui dir, a penjar la toballola i el bikinot» (25-06-2008)

[www.fotolog.com/cherriee/4770524I/]

b. «Els més optimistes diuen que seguirem en caiguda lliure un parells d'anys més.

(Crisassa?)» (18-02-2009)

[emaspons.blogspot.com.es/2009/o2/dir-aixo-crisi-es-immoral.html]

«Sudoket» (títol de passatemps a la revista La Figuereta)

[www.novamuixeranga.com/imgs/lafiguereta/figuereta23.pdf]

\section{NOMS MASCULINS EN - $A$}

a. «Es aquest dramet una flor exquisita de literatura»

[CTILC: Revista setmanal, 9]

«ens tenen ben distrets amb el dramot de l'Estatut» (OI-09-2008)

[bellatxao.blog.cat/2008/09/or/de-ctic/]

«en aquests dramons i entrexocs de passions i d'interessos»

[CTILC: Pàmies, T. (1974)]

"he escrit un poemet a la manera xinesa"

[CTILC: Manent, M. (1975)] 
«sa virtutés prou elàstica per menjar-se un problemet tan específic» (Antònia Font) [www.musicoscopio.com/antonia-font/letras/8297/]

«Zuco, aquest mapet és genial» (I6-OI-20IO)

[www.meteobaleares.com/foro/index.php?topic=98.o]

b. "la tragèdia es queda en drameta»

[www.uv.es/caracters/pdf/CARACTERS-o8.pdf]

"en aquell poemeta pintoresc i costumista»

[CTILC: Sánchez Gozalbo, À. (1934)]

"Algun problemeta té el blog» (15-02-2006)

[personal.telefonica.terra.es/web/oscarmartinez/blog/2006/o2/algun-problemeta-del-blog.html]

«ja hi trobo a faltar el mapeta (d'abast mundial)» (22-05-20II)

[osgeo-org.I56o.n6.nabble.com/Geoinquiets-Barcelona-llista-de-geoinquietsd-arreu-td $4923022 . h t m l]$

\section{NOMS FEMENINS EN -O}

a. «vam sentir el soroll d'aquella moteta» (03-II-2OI2)

[www.elperiodico.cat/ca/noticias/esports/cop-sonar-moto-224I429]

«Una motassa i unes cames poderoses que la guien» (I2-OI-2009)

[www.ecamps.cat/post/63637]

"Aquí teniu una foteta d'aquest matí» (28-II-2OII)

[twicsy.com/i/MbmoV]

«Quina fotassa Ferran!!!» (22-I2-20II)

[nafracendrers.blogspot.com.es/20II/I2/bon-nadal-20II.html]

«amb l'única companyia de la radieta del padrí» (27-07-2008)

[perdudapelmon.blogspot.com.es/2008/o7/verbenes-i-iphones.html]

b. «Amb la motet» (20-07-2009)

[journals.worldnomads.com/dayangchi/photo/18506/534580/Spain/Amb-la-motet] «una fotet de festes!!!» (02-12-2008)

[www.fotolog.com/paquinoenvulga/5132689I/]

«he sentit la necessitat de comprar-me una radiet» (26-03-20II)

[tadeuscalinca.blogspot.com.es/20II/o3/radiet.html] 


\section{NOMS PROPIS MASCULINS EN -ES}

a. $\quad$ «per molts d'anys Elietes» (18-04-2009)

[www.fotolog.com/totrilusio/49354370/]

«Ací no està prohibit pensar, Matietes!» (M. Pallarès)

[books.google.es/books?id=WhxlrUTslZoC]

b. "Tenia la seu social a cal Carlet del raval de Rosselló»

[www.diputaciodetarragona.cat/marc/web/diputacio-de-tarragona/blancafort/ cooperativa-agricola-sindicat-dels-pobres]

«Els orígens de la masia de pagès Cal Carlot es remunten vers el I774»

[http://www.gastroteca.cat/ca/fitxa-oncomprar/cal_carlot/]

«El Carles Salvador, Carletes Martorell pels amics, és un paio formal» (I7-I2-2009)

[www.koalasteam.com/2009/12/17/tenim-nous-koales/]

c. «ixen doncs fets uns herculets einsteinians» (29-02-2008)

[z.blog.cat/2008/02/29/en-verdura-xxi/]

whe de sentir-me voltat d'una dansa de Xenofontets i Socratets i de Richters i

Schenkls» (C. Riba)

[books.google.es/books?isbn=8472838064]

\section{NOMS COMUNS MASCULINS EN -S}

a. «ja feia tempset que no pujava res» (09-10-2006)

[www.fotolog.com/bianus/I7189584/]

«feia tempsot $\mathrm{k}$ no me pasava per aki» (29-II-2007)

[www.fotolog.com/simplmnt_natros9/34407478/]

"Des de fa un tempet a TV3 i Cat Ràdio [...]" (OI-OI-2OI2)

[www.racocatala.cat/forums/fil/153656/alguna-cosa-canvia-c9-arrap-obrint-pas-

pegatina-noticies]

«Corono amb unes 5.05h, això serà un temparro a meta» (06-08-2008)

[culitoweb.blogspot.com.es/2008/o8/quebrantahuesos-2007.html]

«soc nova açi, bueno ja duia un tempets llegint» (I5-08-2006)

[www.racocatala.cat/forums/fil/47152/el-pub-nocturn-raconaire?pag=I2] 
b. «i si quan es diu "temps inestable", el que en realitat es vol dir és "mal temps", perquè no recurrir a velles expressions com: [...] temparrot, tempset, tempsot» (22-05-1998) [oratge.org/estab.html] «Quin bon tempset, quanta platja, airet, i en no res...més!» (25-05-2008) [www.fotolog.com/annagiro/51833573/] "Amb això, i amb es tempsot que fa, estic també una mica "depre"» (oI-05-2006) [www.eivissaconfidencial.com/ro47/la-realitat-a-vegades-supera-la-ficcio] «I demà arribau a anar a sa fira del ram amb aquest tempot q mos fa?» (25-03-2008) [www.fotolog.com/somni_de_paper/41550999/]

\section{NOMS PROPIS FEMENINS I MASCULINS EN -S}

a. Àngels ha dit: [...] Bego ha dit: [...] Ja quedarem. Besets, angeletes!» (23-042007)

[laparaulaesnostra.blogspot.com.es/2007/o4/aci-estem.html] «Angeleta Ferrer i Sensat. Mestra, pedagoga, naturalista. Àngels Ferrer i Sensat [...]» [www.dbd.cat/index.php?option=com_biografies\&view=biografia\&id=I2II] "Angelets Tarragona»

[https://es-es.facebook.com/Angeletstarragona] «La "Doloretes" a la UVIC. [...] Dolors Redondo va impartir [...]» (3I-05-20II) [www.epiagranollers.cat/20II/os/la-la-uvic.html] "Al final vam ballar amb la Doloreta i vam fer una festa» [www.xtec.cat/crp-girones/tarla/tarla_39.pdf] «què és això? uns pantalons? [...] petonets dolorets!!!» (04-03-2007) [www.fotolog.com/dolorains/20650920/]

b. «Comediant Carlets» [es-la.facebook.com/comediant.carlets] «CARLOTS: Ets una persona super important per mi» (27-IO-2007) [www.fotolog.com/durancin/27897125/] 


\section{NOMS GEOGRÀFICS FEMENINS EN -ES I MASCULINS EN -S}

a. $\quad$ «els primers d'aconseguir els bitllets cap Atenetes som nosaltres!!» (02-03-2007) [santdenis.blogspot.com.es/2007/03/cap-la-capital-grega-ja.html] «i dspres ja kap a banyoletes de nou!!!» (o9-OI-2009) [www.fotolog.com/ai_tanyo/59035466/]

b. «des de Cambrils, el meu cambrilets, al Baix Camp» (27-05-2007) [ledu.blog.cat/2007/05/]

«M. Pigens té oberta una exposició de paisatges a la Sala Arenyets» (La Publicitat, 28-03-1924)

[mdc2.cbuc.cat/cdm/compoundobject/collection/publicat22/id/722/show/719/ $\mathrm{rec} / 37447]$

\section{NOMS EN ALTRES TERMINACIONS -VS (-US, -IS, -OS)}

a. «com està mullat? Està xop fins a les cuixes, i el clitoret està tot inflat» [books.google.es/books?isbn=8499300596]

"Desaigüe de l'Eucaliptet. Desaigüe de la comarca del Montsià» [www.enciclopedia.cat/enciclop $\% \mathrm{C}_{3} \% \mathrm{~A} 8$ dies/cerca?s.q=Desaig\% $\% 3 \% \mathrm{BCe}+\mathrm{de}$ $+1 \% 27$ eucaliptet\&search-go=Cerca\#.UVm77pOpWSo]

b. «just vaig agafar un viruset i vaig estar de baixa» (22-03-2006) [elcordelasardina.blogspot.com.es/2006/03/uns-de-viatge-italiaaltres-burriana_22.html]

«mira que t'envio un viruset que t'apagui l'ordinador, eh???» (17-06-2006) [relatsencatala.cat/conversa/aiaiaiaiaaaiiiiiiiiiii-gerard/3I770I]

«Som tres les del fotolog, es diuen sara, venus i jo que em dic andrea! [...] jo sok la venuseta» (29-03-2006)

[www.fotolog.com/punxaaa/I4434448/]

"Un dels koales [...] menjava fulles tant panxo en un eucaliptuset» (17-04-2012) [buscalintrus.wordpress.com/2012/04/17/great-ocean-road-carretera-i-manta/] 
